\title{
THE RIGHT TO PARTITION IN ALBERTA
}

Two recent cases have renewed the interest of the Alberta Bar in the law of partition. The response of the courts to partition has been strikingly different when dealing with two aspects of the public interest; use of the matrimonial home and subdivision control.

In the first case, Clark (Clarke) v. Clarke, ${ }^{1}$ a divorced husband applied for sale of the former matrimonial home under the Partition Act, 1868. ${ }^{2}$ The evidence before the trial judge revealed that the wife was of poor health and suffered severe epileptic attacks. Despite his wife's inability to work, the applicant had made no contribution since their separation for her support or upkeep of the home. He in fact forced her to seek public welfare by quitting his job whenever she sought maintenance. The Court of Appeal upheld the trial judge and refused to order sale in lieu of partition where physical division was impracticable. While the case can be distinguished on the pleadings, [the applicant had failed to claim partition as well as sale] it may have introduced into the law of Alberta a judicial discretion to deny both partition and sale of the matrimonial home.

The second case, Trueman v. Evans et al. ${ }^{3}$ is one of a recent line of cases where co-tenants sought and were granted a consent order for partition, thus effectively circumventing the subdivision provisions of the Planning Act. ${ }^{*}$

\section{BACKGROUND}

At common law, only coparceners had a legal right to demand partition ${ }^{5}$ but with the statutes of 1539 and $1540^{\circ}$ the right to proceed at law for partition was extended to joint tenants, tenants in common and holders of particular estates for life and years. These two statutes used the words, "shall and may"7 be compelled to make partition. Such a phrase is to be construed imperativelys and partition was held to be a matter of right. ${ }^{\circ}$

Meanwhile the courts of chancery had assumed a concurrent jurisdiction with courts of law in partition. ${ }^{10}$ Partition remained a matter of right, however, whether at law or equity ${ }^{11}$ with sometimes absurd results. In one case ${ }^{12}$ a house was divided and the plaintiff got neither chimney nor stairs. ${ }^{13}$ To remedy this situation the Partition Act, 1868, was passed allowing the court a discretion to

1 [1974] 1 W.W.R. 488; aff'd. [1974] 5 W.W.R. 274.

231 \& 32 Vict. c. 40 .

8 Trueman v. Evans, Fisher, Moorish and Atkins (unreported), 1975, \#199472, Alta. S.C.

R.S.A. 1970 , c. 276.

- Patel v. Premabhai [1954] A.C. 35.

31 Henry VIII c. 1 and 32 Henry VIII c. 32.

IIn the 1539 Act, ". . . shall and may be coacted and compelled by vertue of this p'sent act, to make pticon ... " In the 1540 Act, “. . . shall and may be compllable from hensfurth, by writte of partition ... to make severaunce and partition ..."

8 Attorney General v. Lock et al. (1744) 26 E.R. 897; Crump v. Adney \& Page (1833) 149 E.R. 436.

- Parker v. Gerard (1754) 27 E.R. 157; Baring v. Nash (1813) 35 E.R. 214. The removal of the word "shall" from the phrase has resulted in a judicial discretion to refuse partition; in Manitoba, see Fritz v. Fritz (No. 2) (1952) 4 W.W.R. 650, in British Columbia, see Evans v. Evans (No. 2) (1951) I W.W.R. 280 and in Ontario, see Re Hutcheson and Hutcheson [1950] O.R. 265.

${ }^{10}$ Manaton v. Squire (1677) 22 E.R. 1036.

11 Baring v. Nash, supra, n. 9:

12 Turner v. Morgan (1803) 32 E.R. 307.

13 See also Mayfair Property Company v. Johnston, [1894], 1 Ch. 508. 
order sale in lieu of a partition of the land. ${ }^{14}$ These Imperial Statutes are still the law in Alberta and Saskatchewan. ${ }^{15}$

Thus in an Alberta case, Wilkstrand and Mannix v. Cavanaugh and Dillon, ${ }^{10}$ dealing with the partition or sale of a petroleum and natural gas lease of certain lands in Alberta, Mr. Justice Ford stated: ${ }^{17}$

Apart from such discretion as is given by the Partition Act as to sale in lieu of partition, a decree or judgment of partition is a matter of right and not dependent upon the discretion of the court, except where certain acts may be required to be performed as a condition precedent by the doctrine that he who seeks equity must do equity.

The cases are clear that difficulty in making a partition, inconvenience and pecuniary loss are insufficient to bar a co-tenant's right to partition. ${ }^{18}$ There are however, other factors which may withdraw the land from the operation of the partition statutes.

In the Wilkstrand case ${ }^{10} \mathrm{Mr}$. Justice Ford, after stating that partition was a matter of right, continued, "The right to partition may, however, be limited, modified or waived by agreement express or implied." ${ }^{20}$ In the early case of Peck v. Cardwell21 Lord Langdale, M.R. dismissed a Bill for Partition where partition would have been inconsistent with a prior agreement. ${ }^{22}$

As well, section 24 of the Partnership Act $^{23}$ provides that land, unless a contrary intention appears, is to be treated as personal property when acquired by a partnership. This effectively prevents the operation of the partition statutes. $^{24}$

There are also many cases where the right to partition has been denied because the property has been charged with some trust. ${ }^{25}$

More to the point, there is authority for the proposition that partition will not be allowed where it would be contrary to the public interest or liable to shock the conscience of the court. Thus Lord Coke said: ${ }^{20}$

If a castle that is used for the necessary defence of the realme, descend to two or more co-parceners, this may be divided by chambers and rooms, as other houses be. But yet,

for that it is pro bono publico et pro defensione regni, it shall not be divided.

14 For an eloquent statement of the purpose of the Act see Lord Hatherley, L.C. in Pemberton v. Barnes (1871) L.R. 6 Ch. App. 685 at 691.

15 Grunert v. Grunert (1960) 32 W.W.R. 509.

16 [1936] 1 W.W.R. 113.

${ }^{17}$ Id. at 114. At law the court confined its relief to a partition but in equity if there were proper cause, an account of the rents and profits would be directed: Lorimer v. Lorimer (1820) 56 E.R. 934. The claims between tenants in common for occupation rent, repairs, and improvements is beyond the scope of this paper: see generally McCormick v. McCormick [1921] N.Z.L.R. 384, Henderson v. Eason (1851) 117 E.R. 1451, te Jones, Farrington v. Forrester [1893] 2 Ch. 461.

18 Baring v. Nash (1813) 35 E.R. 214.

10 Supra, n. 16.

20 Id. at 115.

21 (1839) 48 E.R. 1131.

22 See also Steele v. Steele (1960) 67 Man. R. 270 where a spearation agreement was held to bar th right to partition.

28 R.S.A. 1970, c. 271.

24 Wild v. Milne (1859) 53 E.R. 993; Crawshay v. Maule (1818) 36 E.R. 479.

25 Taylor v. Grange (1880) 15 Ch.D. 165, Biggs v. Peacock (1882) 20 Ch.D. 200, Keefer v. McKay (1881) 29 Gr. 162.

20 Co. Litt. 165 (a). 
In Brown v. Lutheran Church two churches had united their interests and built a church and graveyard. After more than a generation, discord among the parties erupted, and one side sought partition. Mr. Justice Woodward speaking for the Supreme Court stated: ${ }^{28}$

The sentiment is sound, and has the sanction of mankind in all ages which regards the resting place of the dead as hallowed ground - not subject to the laws of ordinary property, nor liable to be devoted to common uses. We do but express the concurrence of this sentiment which we feel, when we hold that a church and burial ground situated as these now under consideration, and owned by distinct religious societies as tenants in common, are not within the spirit and meaning of the statutes of partition. . . .

\section{MATRIMONIAL PROPERTY}

There are three reported cases dealing with partition of matrimonial property prior to Clark (Clarke) v. Clarke. ${ }^{29}$

In the first case, Re Partition Act, 1868, and Rule 474, Robertson v. Robertson $^{30} \mathrm{Mr}$. Justice Egbert cited the Wilkstrand case $^{31}$ and affirmed that under the Partition Act, 1868, partition, or sale in lieu of partition, was in the ordinary case a matter of right. The issue for his Lordship in this case, however, was whether, if the land was a homestead within the meaning of the 1948 Dower Act, ${ }^{32}$ the right to partition or sale was lost if the applicant failed to acquire the consent of his spouse to a "disposition". His Lordship held that it was, citing with approval the decision of the Manitoba Court of Appeal in Wimmer v. Wimmer.33 where it was held that the property was a "homestead" under the Law of Property Act ${ }^{34}$ and that the plaintiff was not entitled to partition without the consent of his spouse. ${ }^{35}$

The same issue was raised in two cases following Robertson; ${ }^{38} \mathrm{McWilliam}$ v. McWilliam \& Prudential Insurance Company of America ${ }^{37}$ and Wagner v. Wagner. ${ }^{38}$

In the $M c W i l l i a m$ case ${ }^{39}$ Smith J. (as he then was) expressly disagreed with the Robertson case $^{40}$ and held that a sale under the Partition Act was not a "disposition" within the Dower Act ${ }^{41}$ and therefore the consent of the spouse was not required on a partition application. Alternatively it was held, even if

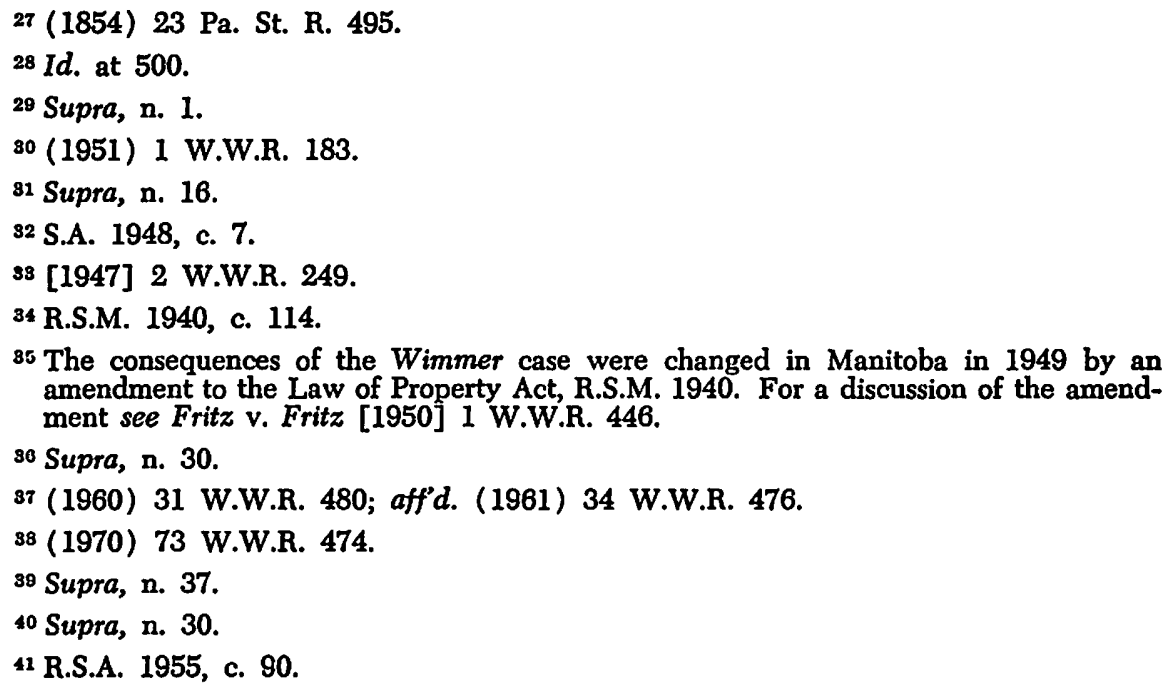


it were a "disposition", the court was prepared to dispense with the husband's consent to the "disposition". The Appellate Division declined to consider the correctness of the Robertson case. ${ }^{42}$

In the Wagner case, ${ }^{43} \mathrm{Mr}$. Justice Kirby agreed with the view of Smith J. that "a sale of land pursuant to the Partition Act, 1868, was not a 'disposition' within the meaning of the word used in the Dower Act."

The significance of holding that a sale of land, pursuant to the Partition Act, 1868, is a "disposition" within the meaning of the Dower Act" is that the courts are given a broad discretion to grant or refuse partition or sale when dealing with the matrimonial home. Subsections $11(4),(5)$ and (6) of the Dower Act set out the matters which the court is to consider on an application to dispense with the consent of a spouse to a "disposition" of lands falling within the Dower Act."s

The issue raised in Robertson v. Robertson ${ }^{48}$ did not arise in Clark (Clarke) v. Clarke $e^{47}$ as the application was not made until several years after the divorce of the parties. However, the court was faced squarely with the prospect of putting a deserving mother on the street on the application of a man whose conduct was not meritorious.

It is arguable that the case could have been resolved against the applicant on the basis of the pleadings. ${ }^{48}$ The Alberta court did not decide on this basis however, and Mr. Justice Allen, speaking for the Court of Appeal quoted sec-

12 Supra, n. 30.

48 Supra, n. 38.

4 R.S.A. 1970 , c. 114 .

45 For a further discussion of these cases See M.C. Cullity, Property Rights During the Subsistence of Marriage, Studies in Canadian Family Law, (Mendes Da Costa; ed.).

46 Supra, n. 30.

47 Supra, n. 1.

18 Sections 3, 4 and 5 of the Partition Act, 1868, which allow for sale in lieu of partition, are premised on a successful claim for partition. Having failed to claim partition it is uncertain whether the applicant is entitled to a sale of the premises. Two early cases are instructive on this point. In Teall v. Watts (1871) L.R. 11 Eq. 213 there was no prayer for partition but only for a sale. Mr. Jessel, Q.C., for the plaintiff, stated in his argument at p. 213 'The Partition Act, 1868, s. 3 only enables the court to decree a sale in a suit for partition, where if the Act had not been passed, a decree for partition might have been made. The bill does not pray for partition, and a question may be raised whether the court has jurisdiction; we therefore propose to amend the prayer.' The Master of the Rolls stated: ' $I$ think the bill had better be amended ..... In the case of Holland v. Holland (1872) L.R. 13 Eq. 406 there was no prayer for partition. It was argued that the decisions upon the point were not uniform. Sir John Wickers, V.C. however required that the bill be amended by adding to it a prayer for partition as well as sale. This uncertainty in the law was resolved by Parliament in the Partition Act, 1876, 39 \& 40 Vict. c. 17, s. 7 . That section provides: 'For the purpose of the Partition Act, 1868, and of this Act, an action for partition shall include an action for sale and distribution of the proceeds, and in an action for partition it shall be sufficient to claim a sale and distribution of the proceeds, and it shall not be necessary to claim a partition.' This section was adopted by the British Columbia, Partition Act. See R.S.B.C. 1960, c. 276, s. 4. However, the Partition Act, 1876, is not part of the laws of England introduced into Alberta by the North-West Territories Act, R.S.C. 1886, c. 50, s. 11 . 
tions 3, 4 and 5 of the Partition Act, 1868,49 and declared without citing authorities that the court had a discretion with regard to the granting of sale in lieu of partition. ${ }^{\text {so }}$ ment:

The significance of the case for Alberta comes from his Lordship's state-

The proposition that because partition is a matter of right sale must be ordered when physical division is impracticable is one which I am not prepared to accept. I think it is clear enough from the sections quoted that in such a situation the remedy of sale is discretionary and the court is not bound to make such an order unless 'it thinks fit' or 'sees good reason to the contrary'.

His Lordship then referred to the evidence before the trial judge and concludes that the discretion to refuse the remedy of sale was fairly exercised against the applicant. ${ }^{52}$

At this stage the applicant, if he had claimed partition as well as sale, was entitled as of right to a physical partition of the premises rather than a dismissal of his application. In subsequent cases however, even when both remedies have been claimed, counsel have argued that the courts have a judicial discretion to refuse both partition and sale of the matrimonial home. ${ }^{53}$ The response of the courts to the recognized public interest in securing the use of the matrimonial home $^{\text {st }}$ may be contrasted to their response to the public interest in subdivision control.

10 3. In a suit for partition, where, if this Act had not been passed, a decree for partition might have been made, then if it appears to the court that, by reason of the nature of the property to which the suit relates, or of the number of the parties interested or presumptively interested therein, or of the absence of disability of some of those parties, or of any other circumstances, a sale of the property and a distribution of the proceeds would be more beneficial for the parties interested than a division of the property between or among them, the court may, if it thinks fit, on the request of any of the parties interested, and notwithstanding the dissent or disability of any others of them, direct a sale of the property accordingly, and may give all necessary or proper consequential directions.

4. In a suit for partition, where, if this Act had not been passed, a decree for partition might have been made, then if the party or parties interested, individually or collectively, to the extent of one moiety or upwards in the property to which the suit relates, request the court to direct a sale of the property and a distribution of the proceeds instead of a division of the property between or among the parties interested, the court shall unless it sees good reason to the contrary, direct a sale of the property accordingly, and give all necessary or proper consequential directions.

5. In a suit for partition, where if this Act had not been passed, a decree for partition might have been made, then if any party interested in the property to which the suit related requests the Court to direct a sale of the property and a distribution of the proceeds instead of a division of the property between or among the parties interested, the court may, if it thinks fit, unless the other parties interested in the property, or some of them, undertake to purchase the share of the party requesting a sale, direct a sale of the property, and give all the necessary or proper consequential directions, and in case of such undertaking being given the court may order a valuation of the share of the party requesting a sale in such manner as the court thinks fits, and may give the necessary or proper consequential directions.

${ }^{80}$ The authorities support the proposition; see In re Dyer. Dyer v. Paynter (1885) 54 L.J. Eq. (1133), Pemberton v. Barmes (1871) 6 Ch. App. 685, Saxton v. Bartley (1897) 48 L.J.' (Eq.) 549.

51 Supra, n. 1 at 278.

82 Id.

s8 Tanner v. Tanner (unreported), 1975, \#116042, distinguishable on the facts; see also Dmytrash v. Dmytrash (unreported), 1974, \#85405, Alta. S. Ct., where the court denied the wife's application for partition or sale of the matrimonial home in which the husband was residing. Unlike Clark (Clarke) v. Clarke the order here provided that the wife might apply for sale at a future time. See also the recent case Re Kornacki and Kornacki (1975) 58 D.L.R. (3d) 159 (Alta. A.D.).

64 The public interest in securing the use of the matrimonial home is discussed in Report 18 of the Alberta Institute of Law Research and Reform on Matrimonial Property. 


\section{SUBDIVISION}

In the Trueman case ${ }^{55}$ there was no issue as to the court's discretion to order sale in lieu of partition. The applicant simply appeared in chambers on an application for partition and the order went on the consent of the four other tenants in common. The order was then registered in the Land Titles Office, effectively subdividing the land without subdivision approval pursuant to the Planning Act.

Trueman, ${ }^{56}$ like Clark (Clarke) v. Clarke, ${ }^{57}$ clearly raises the issue of whether partition is in fact a matter of right in the Province of Alberta.

A present aspect of public interest is that land should not be subdivided without regard to sound planning principles. It is at least arguable that the Alberta courts could have taken judicial notice of the Planning Act and on the ground of public policy denied partition. ${ }^{58}$

In such situations the court could order a sale under s. 3 of the Partition Act, 1868 in lieu of partition as was done by the Privy Council in a Fiji case. ${ }^{50}$ However, it is well known that land is more valuable when divided and no one asks for sale in lieu of partition.

There are some who will argue that the Planning Act encroaches on property rights, particularly the right of subdivision which is an ordinary incident of ownership, and is therefore subject to a strict construction. ${ }^{60}$

It may then be argued, subject to the case of Clark (Clarke) v. Clarke, ${ }^{\text {,1 }}$ that a tenant in common has an absolute right to partition in Alberta.

This results in a straight question of statutory interpretation: does the Planning Act in clear and express language derogate from this absolute right to partition? The narrow issue is: is partition of property pursuant to the partition acts, a subdivision as defined by section $2(s)$ of the Planning Act? That section provides:

'subdivision' means a division of a parcel by means of a plan of subdivision, plan of survey, agreement or any instrument, including a caveat, transferring or creating an estate or interest in part of the parcel.

It appears therefore, that a partition to be a subdivision within the meaning of the Planning Act must meet three basic requirements: (i) There must be a division of the parcel. This requirement must be conceded. (ii) The order for partition must be an instrument within the meaning of the Planning Act. The word "instrument" is not defined in the Act, but s. 23 refers to the kinds of instruments the Registrar shall not accept unless they are approved in accordance with the Act. This section was amended as recently as 1971 but it still does not

\footnotetext{
ss Supra, n. 3.

58 Id.

67 Supra, n. 1.

58 There is one case of which the author is aware - Raaz v. Raaz (unreported), Oct, 1973, \#107561, Alta. S. Ct. - where Manning J. added to the order for partition: This order for partition being subject to approval of appropriate municipal authority and failing such approval the matter to be spoken to again.

50 Patel v. Premabhai [1954] A.C. 35.

${ }^{60}$ Maxwell on Interpretation of Statutes 275 (11th ed.) and Re Corp. of the District of Surrey (1960) 20 D.L.R. (2d) 174, Re Simpson and City of Vancouver (1975) 48 D.L.R. (3d) 215, Re Columbia Estates Co. Ltd. and District of Burnaby (1975) 49 D.L.R. (3d) 123 .

61 Supra, n. 1.
} 
include an order for partition. (iii) There must be a transfer or creation of an estate or interest in part of the parcel. It can be argued that a partition order does not transfer an estate or interest, but does it create an estate or interest? This question involves complex real property law which is beyond the scope of this paper. ${ }^{82}$

The writer's opinion is that a partition order, even if it does not create an estate or interest in part of the parcel, ought not to be used to circumvent the subdivision provision of the Planning Act. $^{63}$

- William R. Pepler ${ }^{\circ}$

- Of the Ontario Bar and the Institute of Law Research and Reform of Alberta. This comment arises out of a project for the Alberta Institute of Law Research and Reform on the Law of Partition. The writer also wishes to acknowledge the assistance given by his colleagues F. A. Laux and U. K. Bhardwaj.

62 The Alberta Institute of Law Research and Reform is in the process of preparing a Partition Act for submission to the Provincial Legislature. No doubt any proposal will take the Planning Act into consideration.

${ }^{68}$ In the meantime at least one municipality, Foothills Municipal District, has filed caveats on the titles resulting from consent orders for partition. 